\title{
Optimization of Dothideomycetes sp. NRC-SSW Chitosanase Productivity and Activity Using Response Surface Methodology
}

\author{
Amal M. Hashem ${ }^{*}$, Shaymaa A. Ismail', Alaa El-Dein M. S. Hosny ${ }^{2}$, Ghada awad ${ }^{1}$, \\ Siham A. Ismail ${ }^{1}$ \\ ${ }^{1}$ Department of Chemistry of Natural and Microbial Products, Division of \\ Pharmaceutical and Drug Industries, National Research Centre, Cairo, Egypt. \\ ${ }^{2}$ Department of Microbiology, Faculty of Pharmacy, Cairo University, Cairo, Egypt.
}

\begin{abstract}
A MONG the methods used for the hydrolysis of chitosan, enzymatic hydrolysis using chitosanase was selected in order to produce high yield of specific chitooligosaccharides with less environmental pollutions. The production of Dothideomycetes sp. NRC-SSW extracellular chitosanase was statistically optimized in which a two - phase experimental design was applied. Plackett - Burman design was used to evaluate the relative importance of culture conditions and medium components for chitosanase production. Chitosan concentration, agitation speed and incubation period were found to be the most significant variables that affected the chitosanase production and their optimal values were obtained by applying Box-Behnken design. The optimized medium composed of $(\mathrm{g} / \mathrm{L})$ chitosan, 30; $\mathrm{K}_{2} \mathrm{HPO}_{4}, 1.5$; $\mathrm{MgSO}_{4}, 0.4 ; \mathrm{KCl}, 4.0$; yeast extract, 18.5 and $\mathrm{FeSO}_{4}, 0.01$; at $\mathrm{pH} 5.5,30^{\circ} \mathrm{C}$ and $180 \mathrm{rpm}$ for $96 \mathrm{~h}$ gave $13.9 \mathrm{U} / \mathrm{mL}$ with $36.3 \%$ increase in the activity. The $\mathrm{R}^{2}$ value was 0.954 and this indicated the aptness of the model. The optimization of the hydrolytic conditions required for chitooligosaccharides production was also performed by Box-Behnken design. The highest yield of chitooligosaccharides was obtained with enzyme/ substrate ratio $0.05 \mathrm{U} / \mathrm{mg}$ in $0.2 \mathrm{M}$ Tris $\mathrm{HCl}$ buffer incubation at $60^{\circ} \mathrm{C}$ for $5 \mathrm{~h}$. The cytotoxic activity of the chitooligosaccharides was tested in vitro against Hep-G2 and MCF7.
\end{abstract}

Keywords: Dothideomycetes sp., Chitosanase, Plackett-Burman design, BoxBehnken design, Chitooligosaccharides, Anticancer.

\section{Introduction}

Chitooligosaccharides (COS) are water soluble derivatives of chitosan that composed mainly of $\boldsymbol{\beta}$-(1-4)-linked D-glucosamine with randomly distributed N-acetyl-D-glucosamine. They have been reported to have remarkable biological activities as well as their potential applications in food, pharmaceutical and agricultural industries $[1,2]$. Recently COS gained a great attention due to their various health benefits as antitumor, anti-inflammatory, anti-hypertensive and hypocholesterimic effects [3, 4]. These various applications attract the research focus to improve the COS productivity to meet the industrial requirements with minimal environmental pollution.

Enzymatic hydrolysis of chitosan to COS has several advantages as it gave specific and high yield of COS with less environmental pollution
[5-7]. Chitosanases are the enzymes that used mainly for hydrolysis of chitosan to COS but their applications are limited due to the high cost and low levels of their production [4]. Several interests are focused to optimize the chitosanase productivity.

Response Surface methodology (RSM) is a statistical technique used successfully in the optimization of complex chemical, biochemical and food process. This technique has received much attention in the investigation of the optimization process for the production of microbial enzymes [7-10].

Fungal chitosanases are poorly studied in comparison to bacterial chitosanases [11, 12]. So in this research a fungal strain identified using 18S rRNA was used for chitosanase production. Statistical optimization with a two level experimental design was carried out as

*Corresponding author e-mail: amal_mhashem@yahoo.com

Telephone: 01022219842 
follow, Plackett - Burman design was applied to identify the most significant factors that influence the chitosanase production then followed by BoxBehnken design to optimize the variables of the highest effect. The optimal conditions required for the production of COS through the hydrolysis of chitosan by the produced enzyme was investigated by applying Box-Behnken design. Also the anticancer activity of the produced COS was evaluated.

\section{Experimental}

\section{Materials}

Chitosan (low and medium molecular weight), glucosamine hydrochloride and yeast extract were obtained from Sigma-Aldrich, Saint Louis, USA. Dinitrosalicylic acid (DNS) was obtained from Panreac, Barcelona, Spain. TLC Silica gel 60 plate was obtained from Merck, Darmstadt, Germany. All other chemicals were of analytical or HPLC grade.

\section{Microorganism}

The fungal strain used in this research was isolated from shrimp shell wastes collected from the local market. The morphological features of the isolated strain were studied under light microscope and scanning electron microscope. Molecular identification of the strain was done by Sigma Scientific Services Co. as follow: DNA extraction was done according to the protocol of Genejet Plant genomic DNA purification using Thermo kit (K0791). PCR was made using Maxima Hot Start PCR Master Mix (thermo K0221) using ITS1 and ITS4 primers. Thermocycling process was done with initial denaturation at $95^{\circ} \mathrm{C}$ for $10 \mathrm{~min}$, denaturation at $95^{\circ} \mathrm{C}$ for $30 \mathrm{sec}$, annealing at $55^{\circ} \mathrm{C}$ for $1 \mathrm{~min}$, extension at $72^{\circ} \mathrm{C}$ for $1 \mathrm{~min}$ and then final extension at $72^{\circ} \mathrm{C}$ for $15 \mathrm{~min}$ for 35 cycles. The PCR product was purified using GeneJET ${ }^{\mathrm{TM}}$ PCR purification thermo kit (K0701). Sequencing of the PCR product was done in GATC Company using ABI 3730xl DNA sequencer using forward and reverse primers.

\section{Chitosanase production \\ Preparation of soluble chitosan for culture medium}

Ten gram of powder chitosan (medium molecular weight) was suspended and dissolved through stirring in $1 \mathrm{~L}$ of $0.1 \mathrm{M} \mathrm{HCl}$ solution $(\mathrm{pH}$ 1.5) then the $\mathrm{pH}$ of the solution was adjusted to 5.5 using $\mathrm{NaOH}(10 \mathrm{~N})$ [13].

\section{Inoculum preparation}

An inoculum culture was obtained by culturing

Egypt. J. Chem. 61, No.6 (2018) the spore suspension of the fungal strain in $250 \mathrm{~mL}$ Erlenmeyer flask contain $90 \mathrm{~mL}$ of sterilized medium composed of $(\mathrm{g} / \mathrm{L})$ chitosan (prepared as indicated above) 2.0; $\mathrm{K}_{2} \mathrm{HPO}_{4} 1.0 ; \mathrm{MgSO}_{4} 0.5$; $\mathrm{KCl} 5.0$; yeast extract 3.0; peptone 5.0; $\mathrm{NaNO}_{3}$ 2.0 and $\mathrm{FeSO}_{4} 0.01$ at initial $\mathrm{pH} 5$ incubated at $30^{\circ} \mathrm{C}$ and $180 \mathrm{rpm}$ for $48 \mathrm{~h}$ [6]. The resulted preinoculated medium was further used to culture the fermentation medium.

\section{Fermentation process}

The fermentation was performed in $250 \mathrm{~mL}$ Erlenmeyer flask contained $90 \mathrm{~mL}$ of the basal fermentation medium resulted after single factor optimization [6] that consisted of $(\mathrm{g} / \mathrm{L})$ : soluble chitosan, 20; $\mathrm{K}_{2} \mathrm{HPO}_{4}, 1.0 ; \mathrm{MgSO}_{4}, 0.3 ; \mathrm{KCl}, 4.0$; yeast extract, $15.0 ; \mathrm{FeSO}_{4}, 0.01$; at $\mathrm{pH} 5$ before autoclaving. The flasks were cultured by $10 \mathrm{ml}$ of the pre-inoculated medium and incubated at $30^{\circ} \mathrm{C}$ in an incubator at $180 \mathrm{rpm}$ for 3 days [6]. At the end of the culture period, the fermented medium was centrifuged at $5000 \mathrm{rpm}$ for $10 \mathrm{~min}$. The clear culture filtrate was used to estimate the chitosanase activity.

\section{Enzyme assay}

Chitosanase activity was assayed using low molecular weight chitosan as a substrate. Chitosan (1\%) was treated with1M acetic acid and adjusted to $\mathrm{pH} 5$ using $2 \mathrm{M}$ sodium acetate before its use as a substrate for enzyme assay [14]. The enzyme activity was determined according to Pagnoncelli et al., [15] by mixing $500 \mu \mathrm{L}$ of the clear culture filtrate with $500 \mu \mathrm{L}$ of $1 \%$ soluble chitosan and the reaction mixture was incubated at $50^{\circ} \mathrm{C}$ for $30 \mathrm{~min}$. At the end of the assay time, $2.5 \mathrm{~mL}$ of DNS was added to stop the reaction. The above reaction mixture with heat inactivated enzyme was used as a blank. The reducing sugars were measured immediately by using DNS method [16] with D-glucosamine as the standard. One unit of chitosanase was defined as the amount of enzyme that released $1 \mu \mathrm{mol}$ of $\mathrm{D}$-glucosamine per minute under the assay conditions.

Statistical optimization of chitosanase production

The optimization study was performed by Plackett - Burman design followed by BoxBehnken design.

\section{Plackett-Burman design}

For multivariable processes such as biochemical systems, in which numerous potentially influential factors were involved, it is necessary to analyze the process with an initial screening design prior to optimization 
using Box and Behnken [17]. Plackett-Burman experimental design [18] was used to evaluate the relative importance of culture conditions and medium components for the production of chitosanase in submerged fermentation (SmF). Seven independent variables were screened in eight trials organized according to the plackett - Burman design matrix described in the results section. For each variable, a high (+) and low (-) level was tested.

Plackett-Burman experimental design was based on the first order linear model:

$\mathrm{Y}=\mathrm{B}_{0}+\Sigma \mathrm{B}_{\mathrm{i}} \mathrm{X}_{\mathrm{i}}$

Where $\mathrm{Y}$ is the response (chitosanase production), $\mathrm{B}_{0}$ is the model intercept and $\mathrm{B}_{\mathrm{i}}$ is the variables estimates. The main effect of each variable was determined by the following equation:

$\mathrm{E}_{(\mathrm{Xi})}={ }^{2}\left(\Sigma \mathrm{M}_{\mathrm{i}}^{+}-\mathrm{M}_{\mathrm{i}}^{-}\right) / \mathrm{N}$

Where $E_{\left(X_{i}\right)}$ is the effect of the tested variable. $\mathrm{M}_{\mathrm{i}}^{+}$and $\mathrm{M}_{\mathrm{i}}^{-}$represent chitosanase production from the trials where the independent variable (Xi) measured was present at high and low concentrations, respectively and $\mathrm{N}$ is the number of trials.

The standard error (SE) of the concentration effect was the square root of the variance of an effect, and the significance level (p-value) of each concentration effect was determined using student's t-test

$\mathrm{t}(\mathrm{Xi})=\mathrm{E}(\mathrm{Xi}) / \mathrm{SE}$

Where $\mathrm{E}(\mathrm{Xi})$ is the effect of variable $\mathrm{Xi}$.

\section{Box-Behnken Design}

In order to describe the nature of response surface in the experimental region, Box-Behnken design [17] was applied. In this model, the most significant independent variables extracted from the above experiment namely $\mathrm{X}_{1}, \mathrm{X}_{2}$ and $\mathrm{X}_{3}$ are included and each factor examined at three different levels, low (-), high (+) and control or basal (0). For predicting the optimal point, a second-order polynomial function was fitted to correlate relationship between independent variables and response (chitosanase biosynthesis). For the three factors the polynomial equation is in the following form:

$\mathrm{Y}=\beta_{0}+\beta_{1} \mathrm{X}_{1}+\beta_{2} \mathrm{X}_{2}+\beta_{3} \mathrm{X}_{3}+\beta_{11} \mathrm{X}_{1}^{2}+\beta_{22} \mathrm{X}_{2}^{2}+$ $\beta_{33} X_{3}^{2}+\beta_{12} X_{1} X_{2}+\beta_{13} X_{1} X_{3}+\beta_{23} X_{2} X_{3} \quad$ Eq. (4)

Where $\mathrm{Y}$ is the predicted response(chitosanase production) and $\mathrm{X}_{1}, \mathrm{X}_{2}$ and $\mathrm{X}_{3}$ are the independent variables corresponding to the concentration of carbon source, shaking speed (rpm) and incubation period respectively; $\beta_{0}$ is the intercept regression coefficient, $\beta_{1}, \beta_{2}, \beta_{3}$ are linear coefficients, $\beta_{11}$, $\beta_{22}, \beta_{33}$ are quadratic coefficients, $\beta_{12}, \beta_{13}, \beta_{23}$ are cross product coefficients.

\section{Partial purification of chitosanase}

This was done by subjecting the crude enzyme (culture filtrate) to fractional precipitation with ethanol at $30-90 \%$ ethanol concentration with $10 \%$ intervals. Each fraction was assayed for chitosanase activity and protein content [19].

\section{Determination of protein content}

The protein content of the enzyme preparations was determined by the method of Lowry et al., [20] using bovine serum albumin as standard.

\section{Hydrolysis of chitosan}

Soluble chitosan $(2 \% \mathrm{w} / \mathrm{v})$ was prepared by dissolving the powder (medium molecular weight) in $1 \mathrm{M}$ acetic acid then adjusted to $\mathrm{pH}$ 4.5 (using $0.2 \mathrm{M}$ Tris $\mathrm{HCl}$ buffer). The reaction mixture contained $2 \mathrm{~mL}$ of $2 \%$ soluble chitosan and different enzyme concentration to reach to enzyme/ substrate ratio (E/S) ranged from 0.0125 to $0.2 \mathrm{U} / \mathrm{mg}$. The reaction was carried out in a shaking water bath at $55^{\circ} \mathrm{C}$ for $4 \mathrm{~h}$. The reaction was stopped by keeping the mixture for $10 \mathrm{~min}$ in boiling water bath. The hydrolysis products of these reactions were identified by silica gel thinlayer chromatography plate using a mixture of propanol: water: ammonia $(7: 2: 1 \mathrm{v} / \mathrm{v})$ as a mobile phase [21]. The amino sugars were visualized with diphenyl amine-aniline reagent [22].

Statistical optimization of the hydrolytic conditions

Box-Behnken design was applied to verify the most suitable conditions to hydrolyze the chitosan to COS. Box-Behnken design was applied in 27run with four factors (Reaction time, temperature, enzyme units and substrate concentration (\%)) and three levels (low (-), high (+) and control or basal (0) including three replicates at the center point and the results were expressed as the amount of reducing sugars released (\%) as reported by Sun et al., [23]. The second-order polynomial equation used to calculate the predicted response was as follow:

$\mathrm{Y}=\mathrm{B}_{0}+\Sigma \mathrm{B}_{\mathrm{i}} \mathrm{X}_{\mathrm{i}}+\Sigma \mathrm{B}_{\mathrm{ii}} \mathrm{X}_{\mathrm{i}}^{2}+\Sigma \mathrm{B}_{\mathrm{ij}} \Sigma \mathrm{X}_{\mathrm{i}} \mathrm{X}_{\mathrm{j}}$ Eq. (5)

Where Y represents response variable, $\beta_{0}$ is the 
interception coefficient, $\beta_{\mathrm{i}}$ the coefficient of the linear effect, $\beta_{\mathrm{ii}}$ the coefficient of quadratic effect and $\beta_{\mathrm{ij}}$ are cross product coefficients, $\mathrm{X}_{\mathrm{i}} \mathrm{X}_{\mathrm{j}}$ are independent variables which influence the response variable $\mathrm{Y}$.

\section{Statistical analysis}

All experiments were performed in triplicates and the averages of the results were reported. The results were statistically analyzed by using the analysis of Variance (ANOVA) techniques, in which $p$ value of $\leq 0.05$ was regarded as significant. Statistical software SPSS (version 16.0) was used for the regression analysis of the experimental data obtained. The quadratic models were represented as contour plots (3D) and response surface curves were generated by using STATISTICA (0.6).

\section{Anticancer activity of the produced COS}

Cytotoxic activities of the produced COS were tested on Human liver cancer cell line (HEP-G2) and Breast cancer cell line (MCF7) according to the method of Skehan et al.[24] and the results were expressed as $\mathrm{IC}_{50}(\mu \mathrm{g} / \mathrm{ml})$ which represented the concentration of the pure chitooligosaccharide (eluted from TLC plates) that reduced survival to $50 \%$. In this method the cells were plated in 96 multi well plate $\left(10^{4}\right.$ cells/well) for $24 \mathrm{~h}$ to allow attachment of the cells to the wall of the plate then different concentrations of the $\operatorname{COS}(0,12.5,2550$ and $100 \mu \mathrm{g} / \mathrm{mL}$ ) were added to the cell monolayer in which triplicate wells were prepared for each individual dose. After incubation in atmosphere of $5 \% \mathrm{CO}_{2}$ for $48 \mathrm{~h}$ the cells were fixed, washed and stained with Sulfo-Rhodamine-B stain. The color intensity was measured in an ELISA reader.

\section{$\underline{\text { Results }}$}

Identification of the chitosanase producing fungal strain

The growth of the fungus on potato dextrose agar (PDA) showed that the color of the fungal spores was dull green. The morphological features of the strain using light microscope and scanning electron microscope were shown in Fig. 1. The partial sequence of the 18S DNA showed $99 \%$ similarity with Dothideomycetes sp. The phylogenetic tree (Fig. 2) also showed that the strain was closely related to Dothideomycetes sp. So the fungus used in this research was identified as Dothideomycetes sp. NRC-SSW.

Optimization of chitosanase production by RSM

The optimization of the medium composition and the culture conditions for extracellular chitosanase production was carried out by statistical methodology.

\section{Plackett - Burman design}

The mean response as the chitosanase activity obtained with the observed response generated in Plackett - Burman was presented in Table 1. The data indicated that there was a wide variation in extracellular chitosanase activity ranged from 1.86 to $11.0 \mathrm{U} / \mathrm{mL}$ that reflected the importance of medium optimization to attain the maximum chitosanase production. The analysis of the data from Plackett-Burman experiment involved a first order (main effects) model. The main effects of the examined factors on the extracellular chitosanase activity were calculated and presented graphically in Fig. 3 offering the view for ranking of factors estimates obtained by Plackett - Burman design. The data in Fig. 3 showed that the extracellular chitosanase production was positively affected by all of the tested factors which indicated that the high concentration of these variables was near to optimum.

The first order model describing the correlation of the seven factors and the chitosanase activity could be presented as follows: $\mathrm{Y}_{\text {Activity }}=-25.113+0.986 \mathrm{X}_{1}+3.148 \mathrm{X}_{2}+0.174 \mathrm{X}_{3}+13$.
$875 \mathrm{X}_{4}+81.875 \mathrm{X}_{5}+0.041 \mathrm{X}_{6}+1.833 \mathrm{X}_{7}$

The $\mathrm{t}$ test, $\mathrm{p}$ effect and the confidence level were presented in Table 2. The variables (chitosan concentration, agitation speed and incubation period) that showed high confidence level in the Plackett-Burman design were selected for further optimization.

\section{Box-Behnken Design}

Box-Behnken design was used to reach the optimum concentration of the most significant chosen variables. The coded and un-coded level of the three independent variables investigated at three different level $(-, 0,+)$ with 15 trials listed in Table 3. The table also showed the Box-Behnken design, the observed and the predicted chitosanase activity. Multiple regression analysis of the experimental data (Table 4) gave the following second order polynomial:

$\mathrm{Y}_{\text {Activity }}=-87.938+48.125 \mathrm{X}_{1}$ $0.056 \mathrm{X}_{2}+22.587 \mathrm{X}_{3}-7.350 \mathrm{X}_{1}^{2}-2.737 \mathrm{X}_{3}^{2}-0.057 \mathrm{X}_{1} \mathrm{X}_{2}$ $+0.750 \mathrm{X}_{1} \mathrm{X}_{3}-0.008 \mathrm{X}_{2} \mathrm{X}_{3} \quad$ Eq. (7)

Where $\mathrm{Y}_{\text {Activity }}$ was the response (chitosanase production) and $\mathrm{X}_{1}, \mathrm{X}_{2}$ and $\mathrm{X}_{3}$ were the coded values of the test variables (chitosan concentration, agitation speed and incubation 


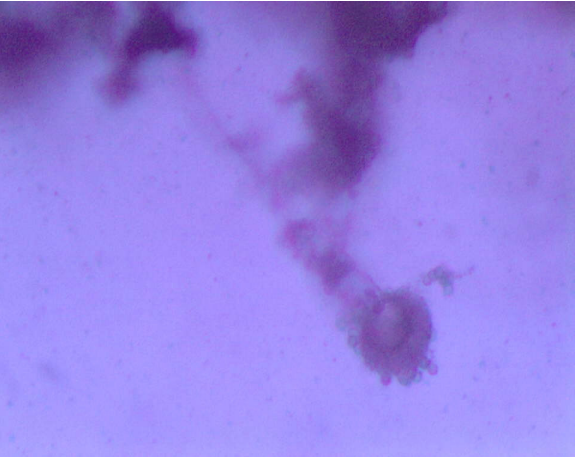

A

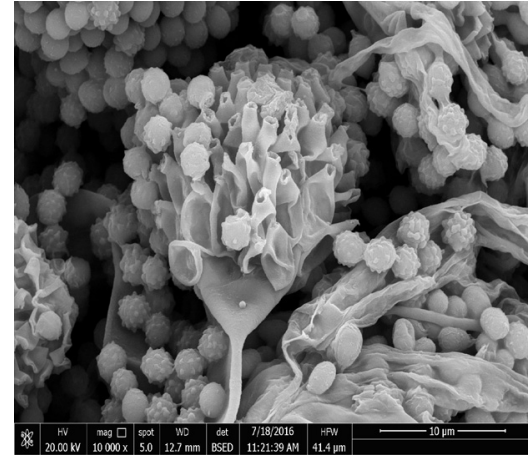

B

Fig. 1. Morphological features of the fungal strain using light microscope (A) and Scanning electron microscope (B).

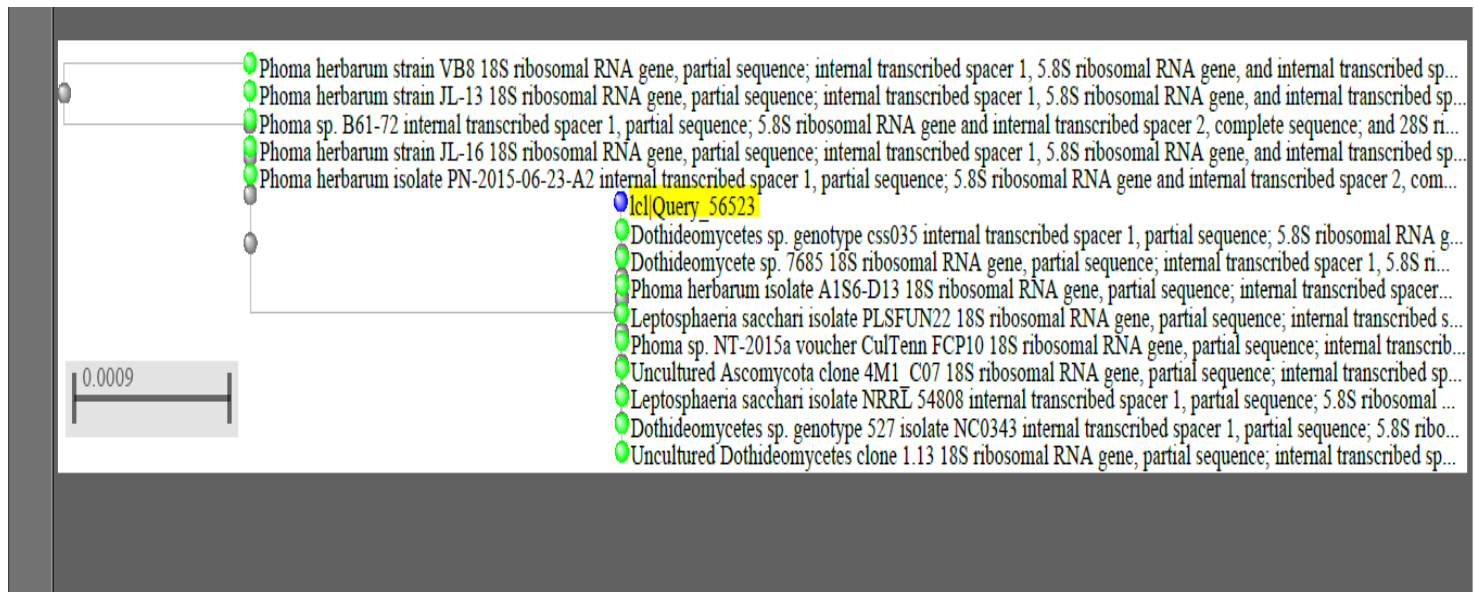

Fig. 2.The phylogenetic tree.

TABLE 1. Plackett - Burman design with coded values and the observed results.

\begin{tabular}{|c|c|c|c|c|c|c|c|c|}
\hline 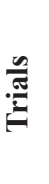 & 总 & 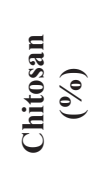 & 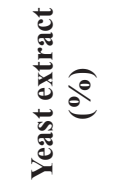 & 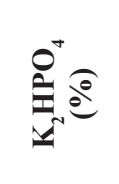 & $e_{i=0}^{+\infty} e^{e}$ & 总 & 衰 & $\begin{array}{c}\text { extracellular } \\
\text { chitosanase }(\mathrm{U} / \mathrm{mL})\end{array}$ \\
\hline 1 & (2) - & (1.5) - & $(1.25)$ - & $(0.15)+$ & $(0.04)+$ & $(210)+$ & (4.5) - & 4.09 \\
\hline 2 & $(4)+$ & (1.5) - & $(1.25)-$ & $(0.05)-$ & $(0.02)-$ & $(210)+$ & $(5.5)+$ & 4.87 \\
\hline 3 & (2) - & $(2.5)+$ & $(1.25)$ - & $(0.05)$ - & $(0.04)+$ & (150) - & $(5.5)+$ & 5.20 \\
\hline 4 & (4) + & $(2.5)+$ & $(1.25)$ - & $(0.15)+$ & $(0.02)$ - & (150) - & (4.5) - & 5.09 \\
\hline 5 & (2) - & $(1.5)$ - & $(1.85)+$ & $(0.15)+$ & $(0.02)$ - & (150) - & $(5.5)+$ & 1.86 \\
\hline 6 & (4) + & (1.5) - & $(1.85)+$ & $(0.05)$ - & $(0.04)+$ & (150) - & (4.5) - & 2.25 \\
\hline 7 & (2) - & $(2.5)+$ & $(1.85)+$ & $(0.05)$ - & $(0.02)$ - & $(210)+$ & (4.5) - & 4.27 \\
\hline 8 & $(4)+$ & $(2.5)+$ & $(1.85)+$ & $(0.15)+$ & $(0.04)+$ & $(210)+$ & $(5.5)+$ & 11.00 \\
\hline
\end{tabular}




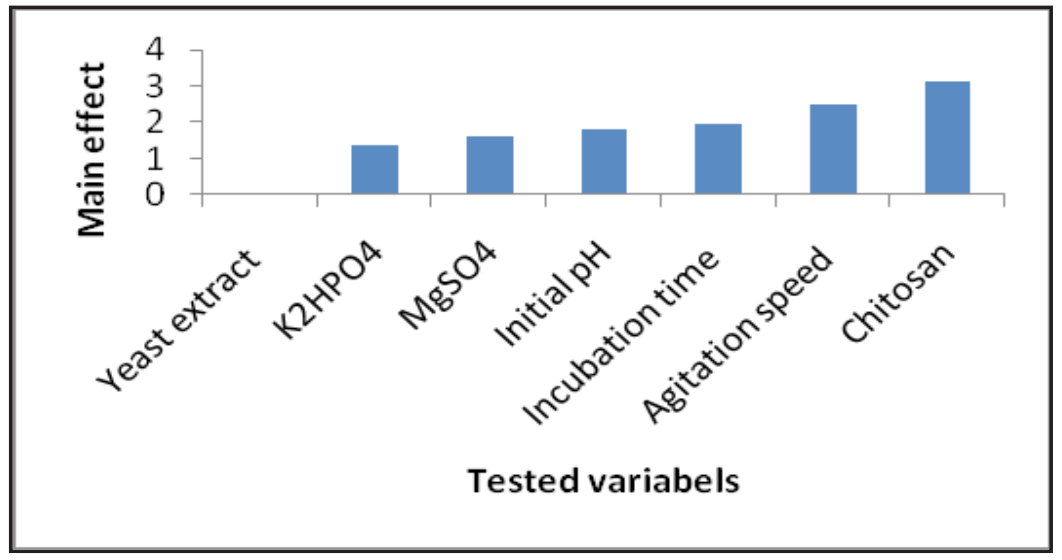

Fig. 3. Main effects of independent variables on extracellular chitosanase production according to the results of the Plackett - Burman experiment.

TABLE 2. Statistical analysis of Plackett- Burman design showing coefficient values, $t$-and $P$ - values for each variable on extracellular chitosanase production.

\begin{tabular}{ccccc}
\hline Variables & \multicolumn{3}{c}{ Chitosanase analysis } \\
\hline Coefficient & t-statistics & $\boldsymbol{P}$-value & $\begin{array}{c}\text { Confidence } \\
\text { level(\%) }\end{array}$ \\
\hline Intercept & -25.113 & & \\
Incubation time (day) & 0.986 & 1.848641 & 0.0535 & 94.65 \\
Chitosan(\%) & 3.148 & 2.949859 & 0.0107 & 98.93 \\
Yeast extract (\%) & 0.174 & 0.053889 & 0.4793 & 52.07 \\
$\mathrm{~K}_{2} \mathrm{HPO}_{4}(\%)$ & 13.875 & 1.300375 & 0.1173 & 88.27 \\
$\mathrm{MgSO}_{4}(\%)$ & 81.875 & 1.534677 & 0.0844 & 91.56 \\
Agitation speed & 0.041 & 2.326617 & 0.0264 & 97.36 \\
Initial pH & 1.833 & 1.717432 & 0.0648 & 93.52 \\
\hline
\end{tabular}

TABLE 3. Examined concentration of the key variables and results of Box-Behnken Design experiments.

\begin{tabular}{|c|c|c|c|c|c|}
\hline \multirow[b]{2}{*}{ Trials } & \multicolumn{3}{|c|}{ Independent variable } & \multirow{2}{*}{$\begin{array}{c}\text { Observed } \\
\text { C.f } \\
\text { Chitosanase (U/ } \\
\text { mL) }\end{array}$} & \multirow{2}{*}{$\begin{array}{c}\text { Predicted } \\
\text { C.f } \\
\text { Chitosanase } \\
(\mathrm{U} / \mathrm{mL})\end{array}$} \\
\hline & $\begin{array}{c}\mathrm{X}_{1} \\
\text { Chitosan(\%) }\end{array}$ & $\begin{array}{c}\mathrm{X}_{2} \\
\mathrm{rpm}\end{array}$ & $\frac{X_{3}}{\text { Incubation time }}$ & & \\
\hline 1 & $2(-)$ & $180(-)$ & $4(0)$ & 8.5 & 8.957 \\
\hline 2 & $3(+)$ & $180(-)$ & $4(0)$ & 13.9 & 13.126 \\
\hline 3 & $2(-)$ & $240(+)$ & $4(0)$ & 6.9 & 7.649 \\
\hline 4 & $3(+)$ & $240(+)$ & $4(0)$ & 8.9 & 8.4160 \\
\hline 5 & $2(-)$ & $210(0)$ & $3(-)$ & 5.3 & 4.737 \\
\hline 6 & $3(+)$ & $210(0)$ & $3(-)$ & 5.8 & 6.455 \\
\hline 7 & $2(-)$ & $210(0)$ & $5(+)$ & 6.3 & 5.618 \\
\hline 8 & $3(+)$ & $210(0)$ & $5(+)$ & 8.3 & 8.837 \\
\hline 9 & $2.5(0)$ & $180(-)$ & $3(-)$ & 9.0 & 9.076 \\
\hline 10 & $2.5(0)$ & $240(+)$ & $3(-)$ & 6.8 & 6.565 \\
\hline 11 & $2.5(0)$ & $180(-)$ & $5(+)$ & 11.0 & 11.206 \\
\hline 12 & $2.5(0)$ & $240(+)$ & $5(+)$ & 7.8 & 7.698 \\
\hline 13 & $2.5(0)$ & $210(0)$ & $4(0)$ & 11.0 & 10.987 \\
\hline 14 & $2.5(0)$ & $210(0)$ & $4(0)$ & 11.0 & 10.987 \\
\hline 15 & $2.5(0)$ & $210(0)$ & $4(0)$ & 11.0 & 10.987 \\
\hline
\end{tabular}

Egypt. J. Chem. 61, No.6 (2018) 
TABLE 4. Analysis of Box-Behnken Design for extracellular chitosanase production.

\begin{tabular}{ccccc}
\hline Term & Regression coefficient & Standard error & t- test & P-value \\
\hline Intercept & -87.938 & 55.377 & -1.588 & 0.210 \\
$\boldsymbol{X}_{1}$ & 48.125 & 16.048 & 2.999 & 0.058 \\
$\boldsymbol{X}_{2}$ & -0.056 & .338 & -0.165 & 0.879 \\
$\boldsymbol{X}_{3}$ & 22.587 & 7.066 & 3.197 & 0.049 \\
$\boldsymbol{X}_{1}^{2}$ & -7.350 & 2.738 & -2.685 & 0.075 \\
$\boldsymbol{X}_{2}^{2}$ & 0.000 & 0.001 & 0.566 & 0.611 \\
$\boldsymbol{X}_{3}^{2}$ & -2.737 & 0.684 & -3.999 & 0.028 \\
$\boldsymbol{X}_{r} \boldsymbol{X}_{2}$ & -0.057 & 0.034 & -1.643 & 0.199 \\
$\boldsymbol{X}_{r} \boldsymbol{X}_{3}$ & 0.750 & 1.035 & 0.725 & 0.521 \\
$\boldsymbol{X}_{2} \boldsymbol{X}_{3}$ & -0.008 & 0.017 & -0.483 & 0.662 \\
\hline
\end{tabular}

$\mathrm{F}$ value $=6.966 ; \mathrm{P}>\mathrm{F}=0.0069 ; \mathrm{R}^{2}=0.954 ; \mathrm{R}=0.977 ;$ Adjusted $\mathrm{R}^{2}=0.817$

period) respectively.

The graphical design of the regression equation was represented by the three-dimensional response surface and the two-dimensional contour plots. They were helpful in understanding both the main and the interaction effects of the factors on the response value. Figure $4 a-c$ showed the response surface and contour plots of chitosan concentration and agitation speed, chitosan concentration and incubation period, also agitation speed and incubation period on chitosanase production respectively, keeping the other variable at the fixed zero level.

The analysis of the results using ANOVA showed a significant F-value (6.966) that indicated the significance of the model. Model terms had values of Prob $>$ F (0.0069) less than 0.05 , considered significant. The coefficient $\left(\mathrm{R}^{2}\right)$ for chitosanase activity was 0.954 that indicated the goodness of the model. The closer the $\mathrm{R}^{2}$ to 1 indicated that the model was useful in predicting the response. The $\mathrm{R}$ value was 0.977 , that was close to 1 indicating a great agreement between the experimental results and the theoretical values predicted by the model equation.

The optimization of the extracellular chitosanase production using RSM increased the enzyme production up to $13.9 \mathrm{U} / \mathrm{mL}$ which was slightly higher than the predicted value $(13.126 \mathrm{U} /$
$\mathrm{mL}$ ) (Table 3) which produced by the use of the medium composed of ( $\mathrm{g} / \mathrm{L})$ chitosan, 30; $\mathrm{K}_{2} \mathrm{HPO}_{4}$, 1.5; $\mathrm{MgSO}_{4}, 0.4 ; \mathrm{KCl}, 4.0$; yeast extract, 18.5 and $\mathrm{FeSO}_{4}, 0.01$; at $\mathrm{pH} 5.5,30^{\circ} \mathrm{C}$ and $180 \mathrm{rpm}$ for $96 \mathrm{~h}$.

\section{Validation of the model}

The validation was carried out under the optimum medium conditions in which the fermentation medium containing 3\% chitosan concentration was used at $180 \mathrm{rpm}$ for 4days incubation period. The experimental chitosanase production of $13.9 \mathrm{U} / \mathrm{mL}$ was obtained and it was close to its predicted value $(13.126 \mathrm{U} / \mathrm{mL})$, validating the proposed model.

\section{Partial purification of chitosanase}

Partial purification of chitosanase by acetone and ammonium sulphate led to a low recovered chitosanase activity (unpublished data). The fraction at $60 \%$ ethanol had the highest recovered activity $47.16 \%$ with specific activity $16.7 \mathrm{U} / \mathrm{mg}$ protein (4.91 times higher than the crude enzyme solution) but this fraction did not show a good stability so the fraction at $30-70 \%$ ethanol with specific activity $8.33 \mathrm{U} / \mathrm{mg}$ protein had higher stability and was used in the next experiments.

\section{Production of COS}

The TLC shown in Fig. 5 indicated that the highest hydrolysis yield of chitosan to COS $(64.8 \%)$ was obtained with $\mathrm{E} / \mathrm{S} \quad 0.05 \mathrm{U} / \mathrm{mg}$ at $55 \mathrm{oC}$ for $4 \mathrm{~h}$. These conditions were subjected 


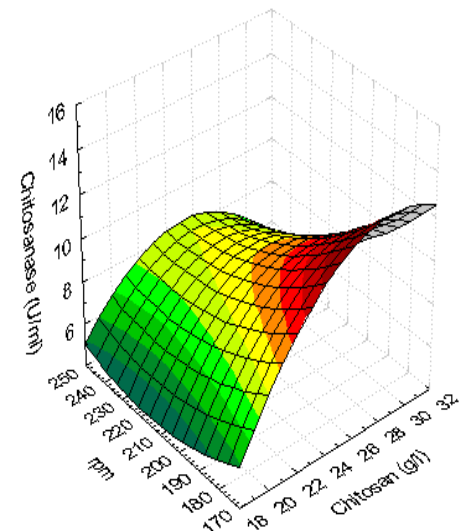

(a)

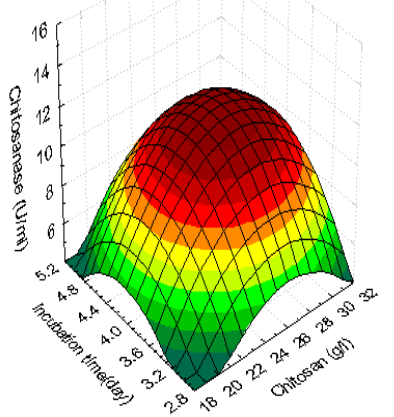

(b)

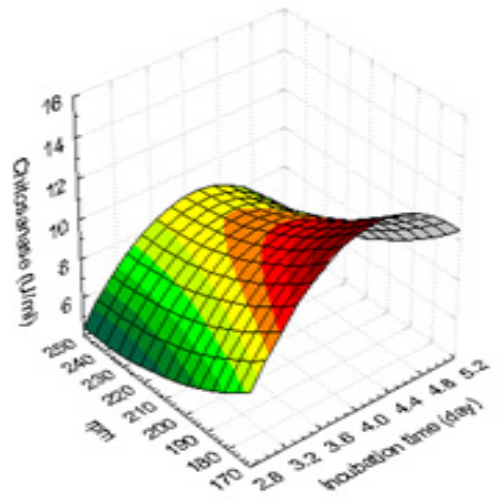

(c)

Fig. 4. Response surface plot of chitosanase production

(a) Showing the interactive effects of different concentrations of chitosan (2-3\%) and different rpm (180-240) at incubation time $=\mathbf{0}$.

(b) Showing the interactive effects of different concentrations of chitosan (2-3\%) and different incubation time (3-5days) at $\mathbf{r p m}=\mathbf{0}$.

(c) Showing the interactive effects of different rpm (180-240) and different incubation time (3-5days) at chitosan concentration $=0$.

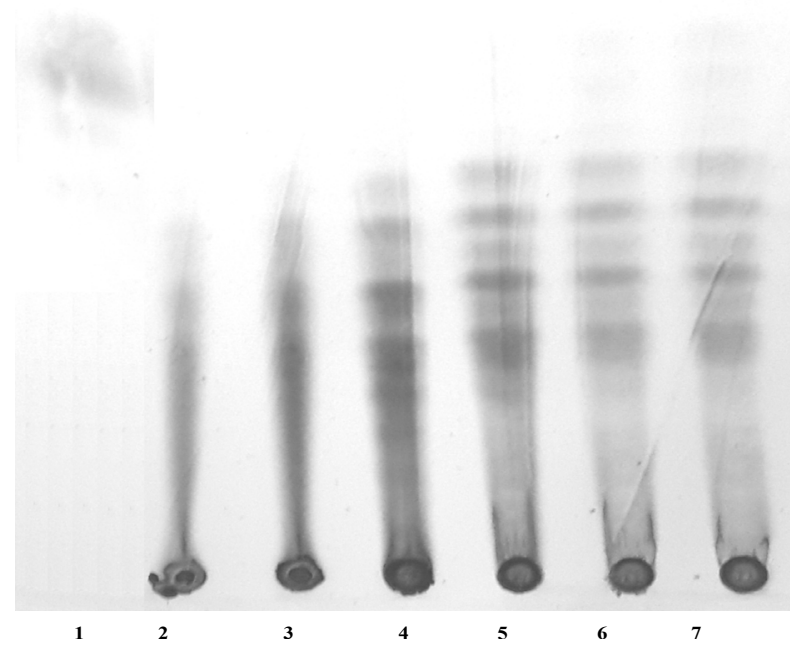

Fig. 5. TLC plate of chitooligosaccharides produced by the hydrolysis of soluble chitosan by chitosanase. Lan 1: glucosamine. Lan 2-9: represent the hydrolysis products different $\mathrm{E} / \mathrm{S}$ ratio $0.0125,0.025,0.05,0.1,0.15$ and 0.2 respectively.

Egypt. J. Chem. 61, No.6 (2018) 
Box-Behnken design for the optimization of hydrolytic conditions

Four variables (reaction time, $\mathrm{X}_{1}$; reaction temperature, $\mathrm{X}_{2}$; enzyme units, $\mathrm{X}_{3}$ and substrate concentration $\left.(\%), \mathrm{X}_{4}\right)$ were chosen to determine their optimal response region in the hydrolysis of chitosan to chitooligosaccharides. The amount of the released reducing sugar (RS) was used as an indicator for the hydrolysis of chitosan.

The variables were examined at three different levels, low (-), high (+) and control or basal (0) and the design matrix of the coded variables together with the experimental and the predicted results were shown in Table 5.
The regression analysis of the data (Table 6) resulted to a polynomial equation that was derived as follow:

$\mathrm{Y}_{\mathrm{RS}(\%)}=217.802-8.916 X_{1}-4.351 X_{2}-36.611$ $X_{3}-48.519 X_{4}+1.612 X_{2}^{2}+0.062 X_{2}^{2}+4.176 X_{3}^{2}$ $+25.075 X_{4}^{2}-0.108 X_{1} X_{2}-0.868 X_{1} X_{3}+2.607 X_{1} X_{4}$ $+0.656 X_{2} X_{3}-0.925 X_{2} X_{4}-0.250 X_{3} X_{4} \quad$ Eq. (8)

where $\mathrm{Y}_{\mathrm{RS}(\%)}$ is the response variable (amount of reducing sugar released \%), $X_{1}$ is the coded value of reaction time, $X_{2}$ is the coded value of reaction temperature, $X_{3}$ is the coded value of enzyme units and $X_{4}$ is the coded value of substrate concentration.

TABLE 5. Box- Behnken experimental design for the optimization of hydrolytic conditions.

\begin{tabular}{|c|c|c|c|c|c|c|}
\hline \multirow{3}{*}{ Trial } & \multicolumn{4}{|c|}{ Independent variables } & \multirow{2}{*}{\multicolumn{2}{|c|}{ RS\% }} \\
\hline & \multirow{2}{*}{$\begin{array}{c}\text { Time } X_{1} \\
\text { (h) }\end{array}$} & \multirow{2}{*}{$\begin{array}{c}\text { Temperature } X_{2} \\
\left({ }^{\circ} \mathrm{C}\right)\end{array}$} & \multirow{2}{*}{$\begin{array}{l}\text { Enzyme U } \\
\mathrm{X}_{3}(\mathrm{U})\end{array}$} & \multirow{2}{*}{$\begin{array}{c}\text { Substrate } \\
\text { conc. } X_{4}(\%)\end{array}$} & & \\
\hline & & & & & Observed & Predicted \\
\hline 1 & $-1(3)$ & $-1(50)$ & $0(2)$ & $0(2)$ & 55.6 & 55.417 \\
\hline 2 & $-1(3)$ & $+1(60)$ & $0(2)$ & $0(2)$ & 74.1 & 71.210 \\
\hline 3 & $+1(5)$ & $-1(50)$ & $0(2)$ & $0(2)$ & 74.1 & 64.203 \\
\hline 4 & $+1(5)$ & $+1(60)$ & $0(2)$ & $0(2)$ & 90.7 & 82.157 \\
\hline 5 & $0(4)$ & $0(55)$ & $-1(1.5)$ & $-1(1.8)$ & 61.1 & 58.481 \\
\hline 6 & $0(4)$ & $0(55)$ & $-1(1.5)$ & $+1(2.2)$ & 74.1 & 63.907 \\
\hline 7 & $0(4)$ & $0(55)$ & $+1(2.5)$ & $-1(1.8)$ & 70.4 & 69.837 \\
\hline 8 & $0(4)$ & $0(55)$ & $+1(2.5)$ & $+1(2.2)$ & 83.3 & 75.163 \\
\hline 9 & $-1(3)$ & $0(55)$ & $0(2)$ & $-1(1.8)$ & 64.8 & 61.127 \\
\hline 10 & $-1(3)$ & $0(55)$ & $0(2)$ & $+1(2.2)$ & 66.7 & 64.418 \\
\hline 11 & $+1(5)$ & $0(55)$ & $0(2)$ & $-1(1.8)$ & 68.5 & 72.037 \\
\hline 12 & $+1(5)$ & $0(55)$ & $0(2)$ & $+1(2.2)$ & 70.4 & 73.242 \\
\hline 13 & $0(4)$ & $-1(50)$ & $-1(1.5)$ & $0(2)$ & 48.1 & 56.558 \\
\hline 14 & $0(4)$ & $-1(50)$ & $+1(2.5)$ & $0(2)$ & 64.8 & 56.558 \\
\hline 15 & $0(4)$ & $+1(60)$ & $-1(1.5)$ & $0(2)$ & 66.7 & 66.912 \\
\hline 16 & $0(4)$ & $+1(60)$ & $+1(2.5)$ & $0(2)$ & 81.5 & 81.495 \\
\hline 17 & $-1(3)$ & $0(55)$ & $-1(1.5)$ & $0(2)$ & 48.1 & 56.292 \\
\hline 18 & $-1(3)$ & $0(55)$ & $+1(2.5)$ & $0(2)$ & 68.5 & 69.335 \\
\hline 19 & $+1(5)$ & $0(55)$ & $-1(1.5)$ & $0(2)$ & 61.1 & 65.291 \\
\hline 20 & $+1(5)$ & $0(55)$ & $+1(2.5)$ & $0(2)$ & 72.2 & 80.070 \\
\hline 21 & $0(3)$ & $-1(50)$ & $0(2)$ & $-1(1.8)$ & 55.6 & 56.918 \\
\hline 22 & $0(3)$ & $-1(50)$ & $0(2)$ & $+1(2.2)$ & 55.6 & 64.144 \\
\hline 23 & $0(3)$ & $+1(60)$ & $0(2)$ & $-1(1.8)$ & 70.4 & 72.400 \\
\hline 24 & $0(3)$ & $+1(60)$ & $0(2)$ & $+1(2.2)$ & 66.7 & 75.926 \\
\hline 25 & $0(3)$ & $0(55)$ & $0(2)$ & $0(2)$ & 64.8 & 64.800 \\
\hline 26 & $0(3)$ & $0(55)$ & $0(2)$ & $0(2)$ & 64.8 & 64.800 \\
\hline 27 & $0(3)$ & $0(55)$ & $0(2)$ & $0(2)$ & 64.8 & 64.800 \\
\hline
\end{tabular}


TABLE 6. Analysis of Box-Behnken Design.

\begin{tabular}{|c|c|c|c|c|}
\hline Term & Regression coefficient & Standard error & t- test & P-value \\
\hline Intercept & 217.802 & 859.732 & 0.253 & 0.804 \\
\hline$X_{1}$ & -8.916 & 25.279 & -0.353 & 0.730 \\
\hline$X_{2}$ & -4.351 & 18.259 & -0.238 & 0.816 \\
\hline$X_{3}$ & -36.611 & 141.484 & -0.259 & 0.800 \\
\hline$X_{4}$ & -48.519 & 443.802 & -0.109 & 0.915 \\
\hline$X_{I}^{2}$ & 1.612 & 1.019 & 1.582 & 0.140 \\
\hline$X_{2}^{2}$ & 0.062 & 0.152 & 0.406 & 0.692 \\
\hline$X_{3}^{2}$ & 4.176 & 15.220 & 0.274 & 0.788 \\
\hline$X_{4}^{2}$ & 25.075 & 91.992 & 0.273 & 0.790 \\
\hline$X_{I} X_{2}$ & -0.108 & 0.332 & -0.326 & 0.750 \\
\hline$X_{I} X_{3}$ & -0.868 & 3.285 & -0.264 & 0.796 \\
\hline $\boldsymbol{X}_{r} \boldsymbol{X}_{4}$ & 2.607 & 7.936 & 0.329 & 0.748 \\
\hline$X_{2} X_{3}$ & 0.656 & 2.053 & 0.319 & 0.755 \\
\hline$X_{2} X_{4}$ & -0.925 & 4.200 & -0.220 & 0.829 \\
\hline$X_{3} X_{4}$ & -0.250 & 41.996 & -0.006 & 0.995 \\
\hline
\end{tabular}

F value $=2.007 ; \mathrm{P}>\mathrm{F}=0.0097 ; \mathrm{R}^{2}=0.809 ;$ Adjusted $\mathrm{R}^{2}=0.879$

Three-dimensional response surfaces (Fig. 6af) were plotted on the basis of the model equation to investigate the interaction among the variables. Figure 7 showed the relation between the observed and the predicted results.

The optimization of the hydrolysis conditions increased the hydrolysis present from $64.8 \%$ to $90.7 \%$. The analysis of the results using ANOVA showed a significant F-value (2.007) that indicated the significance of the model. Model terms had values of Prob $>$ F (0.0097) less than 0.05 , considered significant. The coefficient $\left(\mathrm{R}^{2}\right)$ for the $\%$ of the released reducing sugar was 0.809 which indicated that the statistical model explained $80.9 \%$ of variability in the response.

\section{Anticancer activity}

The cytotoxic activities of the COS mixture eluted from TLC plate were tested on human liver cancer cell line (Hep-G2) and breast cancer cell line (MCF7). The results showed in Fig. 8 indicated that the $\mathrm{IC}_{50}$ of Hep-G2 was $12 \mu \mathrm{g} / \mathrm{mL}$ while the $\mathrm{IC}_{50}$ of MCF7 was $85.5 \mu \mathrm{g} / \mathrm{mL}$ which means that the COS mixture had a stronger cytotoxic activity against Hep-G2 than MCF7.

\section{Discussion}

Chitosanases are specific enzymes used for the hydrolysis of chitosan through the hydrolysis of the $\beta$-(1-4)-glycosidic linkage to produce COS. The use of chitosanase to produce COS has several advantages. Many researchers are focused to find new microorganisms with high level of chitosanase production [1, 7]. In the current research the molecular identification of the chitosanase producer fungal isolate showed 99\% similarity with Dothideomycetes sp. Kirk et al., [25] reported that Dothideomycetes was the largest and the most diverse class of Ascomycetes and it was reported to produce chitosanase by 


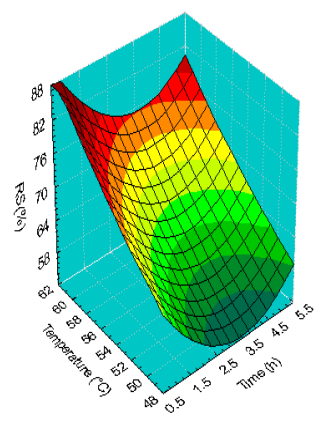

(a)

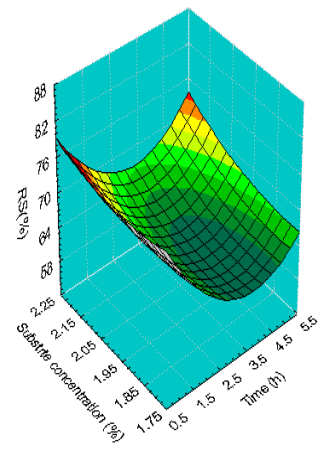

(c)

(e)
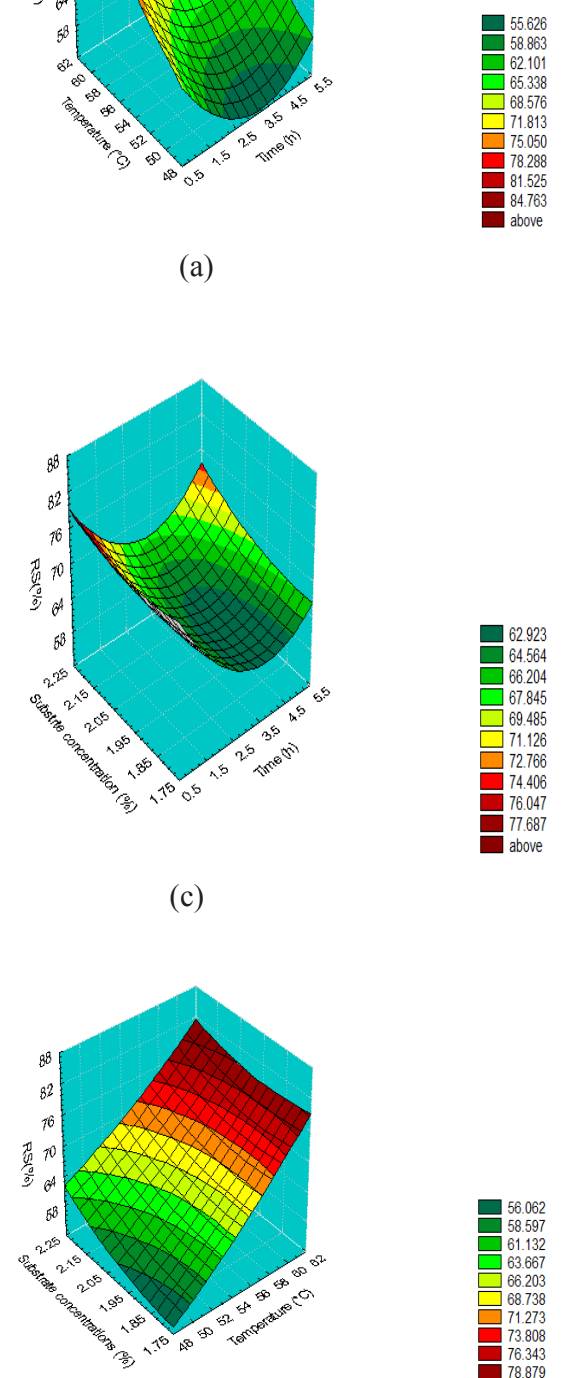

above

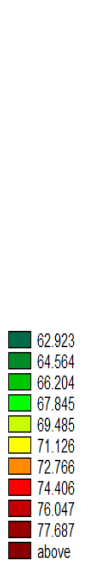

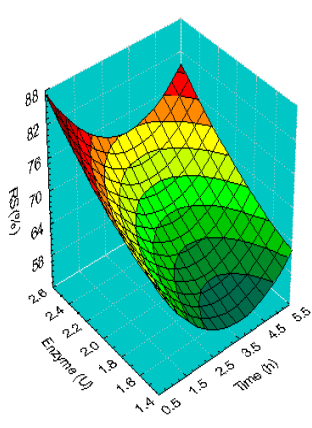

(b)

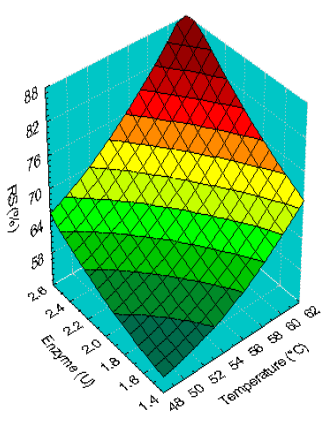

(d)

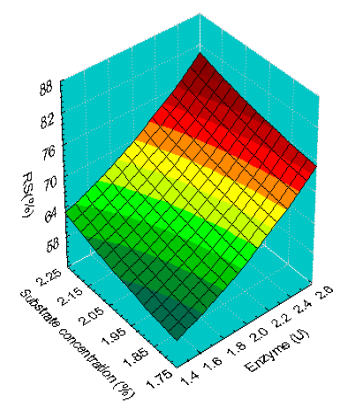

(f)

Fig. 6. Response surface plot of the amount of reducing sugar released \%

(a) Showing the interactive effects of different time (3-5h) and different temperature (50-60oC) at $\mathrm{X} 3=0$ and $\mathrm{X} 4=0$.

(b) Showing the interactive effects of different time (3-5h) and different enzyme units (1.5-2.5U) at X2=0 and $\mathrm{X} 4=\mathbf{0}$.

(c) Showing the interactive effects of different time (3-5h) and different substrate concentrations (1.8-2.2\%) at $\mathrm{X} 2=0$ and $\mathrm{X3}=0$.

(d) Showing the interactive effects of different temperature (50-60oC) and different enzyme units (1.5-2.5U) at $\mathrm{X} 1=0$ and $\mathrm{X} 4=0$.

(e) Showing the interactive effects of different temperature (50-600C) and different substrate concentrations $(1.8-2.2 \%)$ at $X 1=0$ and $X 3=0$.

(f) Showing the interactive effects of different enzyme units (1.5-2.5U) and different substrate concentrations (1.8-2.2\%) at $X 1=0$ and $X 2=0$. 


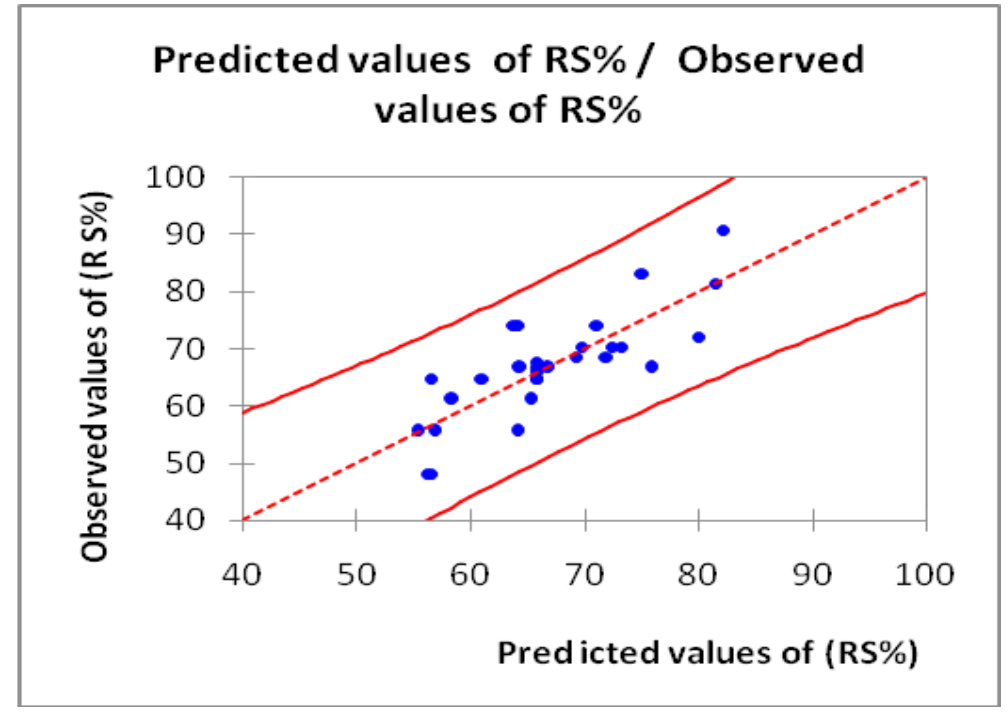

Fig. 7. Correlation between the observed and predicted values for RS $(\%)$ determined by the first-order polynomial equation.
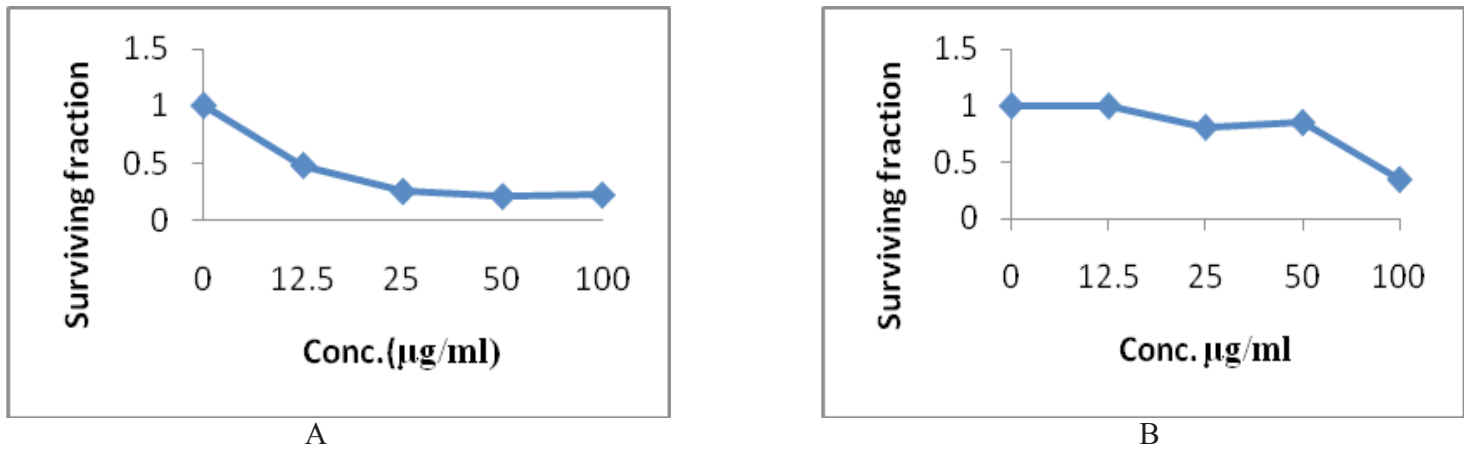

Fig. 8. Effect of different concentrations of COS on Hep-G2 (A) and MCF7 (B).

Ramos-Garza et al., [26] and Zeiner et al., [27].

The application of the statistical optimization of the microbial enzymes using RSM has received much attention [7-10]. So the optimization of the extracellular chitosanase production using RSM was carried out by two-phase multifactorial designs. The first phase involved the application of Plackett-Burman design which indicated that chitosan concentration, agitation speed and incubation period were the most significant variables. Thadathil \& Velappan, [28] and Nidheesh et al., [7] reported that chitosanase was an inducible enzyme and the incubation period was a strong variable that affects the production of the chitosanase from different microorganisms. The variables that showed the highest confidence level in the Plackett-Burman design were further optimized by Box-Behnken design. RSM increased the enzyme activity up to $13.9 \mathrm{U} / \mathrm{mL}$ which was $36.3 \%$ higher than that produced using the basal fermentation medium (10.2U/ $\mathrm{mL}$ ). The optimization of fungal chitosanases by using RSM has been reported by other authors. Zhang and Zhang, [29] reported the production of chitosanase with optimal activity $21.85 \mathrm{U} / \mathrm{mL}$ using Aspergillus fumigates YT-1 by SmF while Nidheesh et al., [7] reported the production of chitosanase with optimal activity $41.78 \mathrm{U} / \mathrm{g}$ initial dry substrate using Purpureocillium lilacinum CFRNT12 by solid state fermentation.

The most interested application of chitosanase was the production of COS that recently known to be a desired molecules for various industries than chitosan due to their low molecular weight, low 
viscosity and its water solubility $[1,2]$. The most stable fraction of the partially purified enzyme was investigated for the hydrolysis of chitosan to $\operatorname{COS}$ and the statistical optimization of the hydrolysis conditions by applying Box-Behnken design increased the hydrolysis present up to $90.7 \%$, which obtained after $5 \mathrm{~h}$ with E/S $0.05 \mathrm{U} /$ $\mathrm{mg}$ at $60^{\circ} \mathrm{C}$. Nidheesh et al., [7] reported the use of chitosanase for the hydrolysis of chitosan with maximum COS production of $54.27 \%$.

COS recently gained a great attention due to their various health benefits as antitumor, anti-inflammatory, anti-hypertensive and hypocholesterimic effects [3, 4]. The cytotoxic activities of the produced COS were tested on HEP-G2 and MCF7. The results indicated that the produced COS had a stronger cytotoxic activity against Hep-G2 $\left(\mathrm{IC}_{50}\right.$ was $\left.12 \mu \mathrm{g} / \mathrm{mL}\right)$ than MCF7 $\left(\mathrm{IC}_{50}\right.$ was $\left.85.5 \mu \mathrm{g} / \mathrm{mL}\right)$. The inhibitory effect of the COS on Hep-G2 was reported by Shen et al., [30] and the anticancer activity of COS has been reported by other authors $[4,31,32]$.

\section{Conclusion}

In conclusion RSM using Plackett - Burman and Box-Behnken designs increased extracellular chitosanase production up to $13.9 \mathrm{U} / \mathrm{ml}$ which was $36.3 \%$ higher than that produced using the basal fermentation medium $(10.2 \mathrm{U} / \mathrm{mL})$. The statistical optimization of the hydrolysis of chitosan to COS with partially purified enzyme increased the hydrolysis products up to $90.7 \%$. The produced COS had a stronger cytotoxic activity against Hep-G2 than MCF7.

\section{References}

1- Hamed I., Özogul F. and Regenstein J.M. Industrial applications of crustacean by-products (chitin, chitosan and chitooligosaccharides): A review. Trends in Food Science and Technology, 48, 40-50 (2016).

2- Liaqat F. and Eltem R. Chitooligosaccharides and their biological activites: A comprehensive review. Carbohydrate Polymers, 184, 243-259 (2018).

3- Sanchez A., Mengibar M., Rivera-Rodriguez G., Moerchbacher B. and Acosta N. The effect of preparation process on the physicochemical characteristics and antibacterial activity of chitooligosaccharides. Carbohydrate Polymers, 157,251-257 (2017).

4- Zou P., Yang X., Wang J., Li Y., Yu H., Zhang Y. and Liu G. Advances in characterization and biological activities of chitosan and chitosan oligosaccharides. Food Chemistry, 190,1174-1181 (2016).

5- Embaby A., Melika R., Hussein A., El-Kamel A. and Marey H. Biosynthesis of ChitosanOligosaccharides (COS) by non-aflatoxigenic Aspergillus sp. strain EGY1 DSM 101520: A robust biotechnological approach. Process Biochemistry, 64, 16-30 (2017).

6- Ismail, S.A., Hosny, A.E.D.M., Ismail, S.A., Abdel-Naby, M.A. and Hashem, A.M. Evaluation of Culture Conditions for Chitosanase Production by Dothideomycetes sp. css035. Inventi Rapid: Pharm Biotech \& Microbio, 4, 1-7 (2016).

7- Nidheesh T., Pal G. K. and Suresh P.V. Chitooligomers preparation by chitosanase produced under solid state fermentation using shrimp by-products as substrate. Carbohydrate Polymers, 121,1-9 (2015).

8- Mohamed L., Kettani Y. E., Ali A., Mohamed E., \& Mohamed J. Application of Response Surface Methodology for Optimization of Extracellular Glucoamylase Production by Candida guilliermondii. Pakistan Journal of Biological Sciences, 20(2), 100 (2017).

9- Mustafa S. R., Husaini A., Hipolito C. N., Hussain H., Suhaili N., \& Roslan H. A. Application of response surface methodology for optimizing process parameters in the production of amylase by Aspergillus flavus NSH9 under solid state fermentation. Brazilian Archives of Biology and Technology, 59 (2016).

10- Yolmeh M., \& Jafari S. M. Applications of Response Surface Methodology in the Food Industry Processes. Food and Bioprocess Technology, 1-21 (2017).

11- Nguyen A. D., Huang C. C., Liang T. W., Nguyen V. B., Pan P. S. and Wang S. L. Production and purification of a fungal chitosanase and chitooligomers from Penicillium janthinellum D4 and discovery of the enzyme activators. Carbohydrate Polymers, 108, 331-337 (2014).

12- Singh P. S., \& Vidyasagar G. M. Isolation, purification and optimization of chitosanase production from a common mahabubnagar agricultural field fungi Aspergillus fumigates of telangana state. World Journal of Pharmacy and Pharmaceutical Sciences, 6(9), 886-898 (2017).

13- Choi Y.J., Kim E.J., Piao Z., Yun Y.C. and Shin Y.C. 
Purification and characterization of chitosanase from Bacillus sp. Strain KCTC 0377BP and its application for the production of chitosan oligosaccharides. Applied and Environmental Microbiology, 70, 4522-4531 (2004).

14- Uchida, Y. and Ohtakara A. Chitosanase from Bacillus species. Methods in Enzymology, 161, 501-505 (1988)

15- Pagnoncelli M. G., Araujo N. K., Silva N. M., Assis C. F., Rodrigues S. and Macedo G. R. Chitosanase production by Paenibacillus ehimensis and its application for chitosan hydrolysis. Brazilian Archives of Biology and Technology, 53, 14611468 (2010).

16- Miller G.L. Use of dinitrosalicylic acid reagent for determination of reducing sugars. Analytical Chemistry, 31, 426-428 (1959).

17- Box G. E. P. and Behnken D. W. Some new three level designs for the study of quantitative variables. Technometrics, 2, 455-475 (1960).

18- Yu X., Halett S. G., Sheppard J. and Watson A.K. Application of the Plackett-Burman experiment design to evaluate nutritional requirements for the production of Colletotrichum coccodes spores. Applied Microbiology and Biotechnology, 47(3), 301-5 (1997).

19- Ismail S. A. Physiological and biochemical studies of microbiological production of chitosanase. $C U$ Theses, (2016).

20- Lowry O. H., Rosebrough N. J., Farr A. L. and Randall R. J. Protein measurement with folin phenol reagent. Journal of Biological Chemistry, 193, 265-275 (1951).

21- Cabrera J. C. and Cutsem P. V. Preparation of chitooligosaccharides with degree of polymerization higher than 6 by acid or enzymatic degradation of chitosan. Biochemical Engineering Journal, 25, 165-172 (2005).

22- Tanaka T., Fujiwara S., Nishikori S., Fukui T., Takagi M. and Imanaka T. A. Unique chitinase with dual active sites and triple substrate binding sites from the hyperthermophilic Archaeon Pyrococcus Kodakaraenis KODI. Applied and Environmental Microbiology, 15, 5338-5344 (1999).

23- Sun Y., Zhang J., Wu S., and Wang S. Preparation of D-glucosamine by hydrolysis of chitosan with chitosanase and $\beta$-D-glucosaminidase. International Journal of Biological
Macromolecules, 61, 160-163 (2013).

24- Skehan P., Storeng R., Scudiero D., Monks A., McMahon J., Vistica D., Warren J. T., Bokesch H., Kenney S. and Boyd M. R. New colorimetric cytotoxicity assay for anticancer drug screening. Journal of the National Cancer Institute, 82(13), 1107-1112 (1990).

25- Kirk P. M., Cannon P. F., Minter D. W. and Stalpers J. A. Dictionary of the Fungi $\left(10^{\text {th }}\right.$ ed.). Wallingford, CABI. P. 221 (2008).

26- Ramos-Garza J., Rodríguez-Tovar A. V., FloresCotera L. B., Rivera-Orduña F. N., VásquezMurrieta M. S., Ponce-Mendoza A. and Wang E. T. Diversity of fungal endophytes from the medicinal plant Dendropanax arboreus in a protected area of Mexico. Annals of Microbiology, 66, 991-1002 (2016).

27- Zeiner C. A., Purvine S. O., Zink E. M., PasaTolic L., Chaput D. L., Haridas S., Wu S., LaButti K., Grigoriev I. V., Henrissat B. and Santelli C. M. Comparative Analysis of Secretome Profiles of Manganese (II) Oxidizing Ascomycete Fungi. Plos one, 11(7), e0157844 (2016).

28- Thadathil N. and Velappan S. Recent developments in chitosanase research and its biotechnological applications. Food Chemistry, 150, 392-399 (2014).

29- Zhang $H$. and Zhang W. Induction and optimization of chitosanase production by Aspergillus fumigatus YT-1 using response surface methodology. Chemical and Biochemical Engineering Quarterly, 27(3), 335-345 (2013).

30- Shen K. S., Chen M. H., Chan H. Y., Jeng J. H. and Wang Y. J. Inhibitory effects of chitooligosaccharides on tumor growth and metastasis. Food and Chemical Toxicology, 47(8), 1864-1871(2009).

31- Azuma K., Osaki T., Minami S. and Okamoto Y. Anticancer and anti-inflamatory properties of chitin and chitosan oligosaccharides. Journal of Functional Biomaterials, 6, 33-49 (2015).

32- Mourya V. K., Inamdar N. N., and Choudhari Y. M. Chitooligosaccharides: Synthesis, Characterization and Applications. Natural Polymers, 53(7), 583-612 (2011).

(Receieved 4/6/2018; accepted $11 / 7 / 2018$ ) 


\title{
تعظيم انتاج انزيم الكيتوزانيز بواسطه فطر الاسودوميستس وزياده قدرته علي

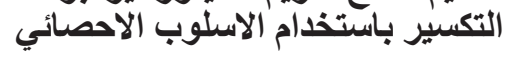

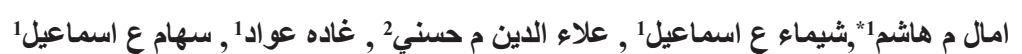

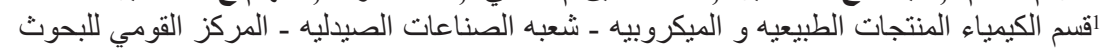

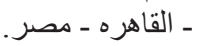 2قسم الميكروبيولوجيـ كليه الصيدله - جامعه القاهره ـ القاهره ـ مصر.
}

\begin{abstract}
تم استخدام الاسلوب الاحصائي لزياده انتاج فطر الدسودوميسيتس لانزيم الكيتوز انيز. وجد ان تركيز الكيتوزان,

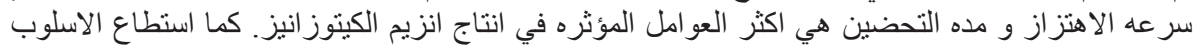

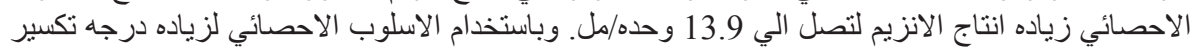

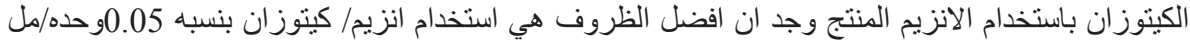
جر ام عند 60 درجه حراره لمده 5ساعات.
\end{abstract}

